\title{
Introduction: Assimilation and Representation in Medieval Theories of Cognition
}

\author{
José Filipe Silva \\ University of Helsinki, Finland \\ jose.pereiradasilva@helsinki.fi \\ Christina Thomsen Thörnqvist \\ University of Gothenburg, Sweden \\ christina.thornqvist@gu.se
}

\begin{abstract}
The articles in this issue are a selection of the papers presented at the conference Knowledge as Assimilation, held at the University of Helsinki on 9-11 June 2017. The conference was the result of a collaboration between two research groups that have been established in Finland and Sweden from 2013 onwards: the research project Rationality in Perception: Transformations of Mind and Cognition 1250-1550, funded by the European Research Council (2015-2020) and hosted by the University of Helsinki, and the research programme Representation and Reality: Historical and Contemporary Perspectives on the Aristotelian Tradition, funded by the Riksbankens jubileumsfond (2013-2019) and located at the University of Gothenburg.
\end{abstract}

\section{Keywords}

assimilation - representation - Medieval philosophy - theory of cognition

The aim of the following introduction is to provide the reader of this special issue of Vivarium with a general backdrop to the individual contributions here included.* In this brief overview, we try to show that the description of

* As the principal investigators of the two projects, Rationality in Perception (https://blogs .helsinki.fi/rationality-in-perception/) and Representation and Reality (https://representation andreality.gu.se/), and as guest editors, we would very much like to thank our respective 
'cognition as assimilation' does play a role in medieval philosophy, but that this description is so implicit in the Aristotelian cognitive model that it has not been frequently spelled out. We have tried to trace some of the ways that this description was explicitly used by key figures in the late medieval period and what the underlying philosophical motivation for their use was. Needless to say, the text that follows should be taken as a tentative rather than exhaustive overview.

\section{$1 \quad$ Becoming Like}

'Assimilation' is a key concept in one of the oldest descriptions of cognition, originating in Aristotle's statement that

[P1] what has the power of sensation is potentially like what the perceived object is actually; that is, while at the beginning of the process of its being acted upon the two interacting factors are dissimilar, at the end the one acted upon is assimilated to the other and is identical in quality with it. ${ }^{1}$

In [P1], Aristotle addresses a key component in his theory of perception, namely that the perceptual power ("the power of sensation") is in a state of passive potentiality (is "potentially like") with respect to the object, which is in the corresponding state of active potentiality - that is, the object is able to bring the power to the full actuality of operation. To give just one example, sight or the power for seeing colour is actualized by the presence of a coloured object. Aristotle explains elsewhere that an episode of veridical visual perception takes place whenever the conditions in the medium and bodily sense organs are optimal and that under these conditions the individual sense modalities are infallible. ${ }^{2}$ Despite being a fairly simple model from a general point of view, the truth is that the exact meaning of assimilation in this context remains both

funders, the contributors, the anonymous referees, and the Vivarium editors-in-chief for the opportunity to edit this issue and for their encouragement and assistance in all matters related thereto. Many thanks also to Christian Kny and Jordan Lavender for their assistance in the preparation of this article and to Ylwa Sjölin Wirling for her assistance with the formatting of all the contributions to the present special issue.

1 Aristoteles, De anima II, c. 5: 418a3-6 (trans. J.A. Smith, in The Complete Works of Aristotle, Princeton, NJ, 1984, 665 [emphasis added]).

2 Aristoteles, De anima III, c. 3: 428b18-22; see also De anima II, c. 6: 418a7-17; De anima III, c. 6: 43ob29-30; De sensu, c. 4: 442b8-10. 
largely unclear and disputed, just like another vexing Aristotelian expression that perception is "the reception of form without matter" (De anima II, c. 12: 424a16-19). But one of the tasks of the historian of philosophy is precisely to interpret statements such as these in relation to the immediate context of a thinker's thought, the proximate context of her historical setting, and the remote context of the place of expressions such as these - and the underlying theory, if there is one - in the history of philosophical thought. We will here focus on the application of assimilation as a description of perception.

In addition to the perceptual implications of the definition of cognition as a form of assimilation, there are other aspects of assimilation that were relevant to the historical period under consideration. We are thinking in particular about the conception of assimilation as a mode of participation that is often used to describe the relation between human beings and God, in which humans attempt to demonstrate their moral worthiness to the Creator by means of their actions and thus aim at participating in or being assimilated to God. ${ }^{3}$ Furthermore, assimilation is also used in the context of pure physiological processes, such as the taking in of nutrients in the process of digestion. There is also the idea, found in ancient thought and, among Latin authors, in Nemesius of Emesa, of the air as assimilable to objects in the surrounding environment, so that once in contact with something, whatever its nature, the air transmits this information further onwards. ${ }^{4}$

What these cases make clear is that the use of the concept of assimilation by ancient and medieval thinkers is not restricted to cognitive contexts. Although these non-cognitive cases of assimilation are not the focus of this paper, they share a significant feature with the cognitive case that is useful for understanding it: assimilation requires, as a starting point, the existence of two different things - whatever these may be - that are unlike one another. But it also requires that these be similar to one another in some relevant respect because something is receptive of something else in such a way that it can become like that thing if and only if there is an underlying structure that makes the 'becoming like another' possible. ${ }^{5}$ Let us call this the 'principle of likeness'.

3 See, e.g., Thomas Aquinas, Summa theologiae I, q. 50, a. 1. See also P. Michaud-Quantin, $L a$ Psychologie de l'activité chez Albert le Grand (Paris, 1966), 246.

4 Nemesius Emesenus, De natura hominis, c. 6 (ed. G. Verbeke and J.R. Moncho, Leiden 1975, 75.38-39): "Quoniam autem aptus natus est aer appropiantibus corporibus assimilari."

5 See, e.g. Avicenna, Liber de anima seu sextus de naturalibus I, c. 5 (ed. S. Van Riet, Louvain-Leiden, 1972, 80.7-10: "Nutrimentum autem est corpus quod solet assimilari naturae corporis cuius dicitur esse nutrimentum, et restaurat ei quantum resolutum est de illo, aut plus, aut minus"; see also II, c. 1 (104.20-21): "Ergo virtus nutritiva restaurat quod solutum est, et assimilat et unit"; and Albertus Magnus, De anima II, tract. 2, c. 6 (Opera omnia V, 
In Aristotelian terms, this means that the thing that is assimilated has something in its composition or structure that is receptive of the action of the agent. For instance, in the case of digestion, the living being must have the power to process the food ingested and its matter must be receptive to the nutrients in the food. Likewise, the food ingested is only capable of acting upon a power so that it activates its digestive capacities if its nutrients are such that they trigger the activity of the digestive power. ${ }^{6}$ The consequence of digestion, growth, is nothing but the assimilation of nourishment into the body of the living thing; but assimilation only works because the body of the living thing is constituted by the same elements that constitute the food ingested. ${ }^{7}$

Applied to perception (and downplaying the dissimilarities), this 'principle of likeness' means that the cognitive power needs to be instantiated in the kind of matter that is receptive of a certain type of sensible property (like color) within a specific range (or spectrum). ${ }^{8}$ For example, the eye needs to be transparent for sight to operate in a way that is receptive and perceptive of the colours as they exist in external things. Notice that this requirement is key to understanding assimilation: it is a process of becoming like $x$, rather than becoming $x$. This is particularly important in the case of cognition, because 'like' can be understood - and misunderstood - in a number of significant ways, from literalist to metaphorical. Whatever way this is read, it seems clear that 'becoming like' in the cognitive sense entails taking on the form of the thing cognized in such a way that as a result one becomes aware of that thing. Thus understood, assimilation entails both realism and intentionality: a cognition is about something other than itself that is made present to a subject in a cognitively significant way. By 'in a cognitively significant way' we mean having the power to trigger the action or operation of sensation, which is for the cognitive subject to become aware of an object as having such a sensible property.

ed. A. Borgnet, Paris, 1890, 223a): "quia ad illius incrementum non exigitur nisi assimilatio nutrimenti, et additio." The concept is also used in the context of explaining generation, for instance in Averroes, Commentarium magnum in De anima II, comm. 35.

6 An interesting case is the explanation of the vegetative soul's inability to perceive. Plants can be materially affected and changed by their surroundings (by heat or cold, for instance), but due to their composition, which according to Aristotle is too simple, they are unable to separate the form from the matter; hence, they can only receive the form with the matter (See De anima II, c. 12: 424a32-424b3; III, c. 13: 435a17-435b1).

7 See, e.g., P.L. Reynolds, Food and the Body. Some Peculiar Questions in High Medieval Theology (Leiden, 1999), 215-234 (for Albert) and 361-371 (for Aquinas).

8 The application of this principle - that that which is affected must be affected by what is like - to perception is clearly spelled out by Philoponus, On Aristotle On the Soul 2.1-6, II, c. 5 (trans. W. Charlton, London, 2005, 96-99). He argues that the power is, prior to activation, like the object in potentiality but unlike the object in actuality. 
Such an understanding of cognition as assimilation as found in historical sources is very different from what is found in contemporary debates. Most of the contemporary philosophical (and psychological) use is focused on the process of integrating knowledge in already existing knowledge structures and pools of background information. In other words, assimilation is, in contemporary debates, not so much about the process of acquiring new knowledge as it is about the process of integrating new knowledge into an already existing knowledge base. One of the reasons why assimilation has acquired this signification is the work of Jean Piaget (1896-1980). In a number of important publications, Piaget outlined his theory of cognitive development, according to which learning includes both a number of stages - each with its own defined goals and sets of characteristics - and an underlying mechanism of knowledge acquisition. This mechanism is constituted by two aspects, assimilation and accommodation. Whereas accommodation means a re-arranging of conceptual schemes as the result of new incoming and non-fitting information, assimilation corresponds to the process by which one adds new knowledge to already existing knowledge in a non-conflicting way. ${ }^{9}$

In contrast, assimilation, for most of the historical period we deal with in this special issue, refers to the more immediate process of how, at the sensory level, we react to sensory stimuli or how, at the intellectual level, we come to be in a state of knowing intelligible objects. The sensory reaction is determined by the constitutive metaphysical structure of our cognitive powers that makes them sensitive to certain features of the environment. ${ }^{10}$ For example, the power of sight is hardwired for the perception of colour, which is its proper object. At the level of the intellect, which is usually defined as the power capable of knowing all things, the objects of intellection must be made accessible in such a way that this capacity can be exercised. At both levels - sensory and intellectual - assimilation is defined as 'becoming like', but whereas sense powers are restricted in their action by their material substrate (the sense organs) and by the particular nature of their objects, intellectual powers are free from both such restrictions, since medieval authors hold that the intellect needs no bodily organ in order to perform its operations. ${ }^{11}$ However, this

9 J. Piaget, The Development of Thought: Equilibration of Cognitive Structures, trans. A. Rosin (New York, 1977).

10 On this, see Mohan Matthen's contribution to this volume.

11 As one referee forcefully pointed out, there are clear differences between the sensory and intellectual processes of assimilation, which may require a separate analysis. Accepting this as a valid note of caution, we still feel that taking elements from both allows us to identify certain patterns in how the issue was discussed in the period under examination. 
way of characterizing assimilation still remains quite vague and thus requires further clarification.

A good starting point is to consider what it means to say that, in the process of assimilation, what is unlike becomes like or is made to be like. Already this way of introducing the issue reveals some important assumptions about the causal story of this process: on the one hand, we can emphasize the passive ('to be made') or, on the other, the active ('to become') nature of the process. That assimilation is a process is demonstrated by the fact that it implies a change, whatever the causal direction. As such it requires the existence of that which is changed, the undergoing subject, and what changes it, the agent of change. As a change, it also means that there are two distinct stages: the starting stage, when something is what it is independently of being acted upon by something else, and the second stage, when it comes to be like something else as the result of being acted upon. Two immediate questions arise from this: first, what is the relation between the two states the changeable thing is in prior to and as the result of that change? Second, what exactly is the relation between the cause of the change and the thing that is in a state of being changeable into something else? The first question is about the nature of the change internal to the changeable thing, the second about the relation between the effect (the change) and its cause.

The second question can be answered in two ways: either the cause of that change is internal to the subject or it is external to the subject, in which case the relation between the two (i.e., external cause and cognitive subject) must be explained. In addition, it is important to ask whether to become like (or to be made like) purports to describe a physiological process or a psychological process, like that of awareness, or both. Here we can refer back to Aristotle and his De anima, where he makes clear that the 'becoming like' is accompanied by a type of psychological act by which the subject becomes aware of the external object. $^{12}$

12 Again, Philoponus makes this point with great clarity when he notes that when/by being acted upon by the external sense object, the sense power "becomes in act a thing which perceives" (On Aristotle On the Soul 2.1-6, II, c. 5 [trans. Charlton, 99], our emphasis). In other words, the being affected is significant because it is a way of being cognitive. A significantly more dualist account can be found in Simplicius, On Aristotle On the Soul 3.6-13, III, c. 13 (trans. C. Steel, London, 2013, 144), who notes that only the sense organ is changed directly by the action of the external thing; the power, which uses the organ as its instrument, is mediately affected by the affection of the organ. 
Now, is the relation between my becoming aware and my becoming like one of identity or of supervenience? ${ }^{13}$ In other words, does my becoming aware co-vary with my becoming like, or is my becoming aware the same as my becoming like? Another way of asking this is whether the above formulation is precise enough, because it seems to leave open which of these two alternatives is the case: do I, by becoming like $\mathrm{x}$, become aware of $\mathrm{x}$, in which case becoming like just is to become aware - the relation is thus one of identity -; or by becoming like $\mathrm{x}$, am I in a state, whatever its metaphysical status, that fulfils a necessary condition for my becoming aware of $\mathrm{x}$ - in which case, the relation is one of supervenience? According to this second alternative, to become like is a necessary but not sufficient condition for cognition. Finally, we still need to ask the really hard question of what the benefit of understanding cognition as assimilation is.

Our suggestion is that medieval thinkers, especially those in the Aristotelian tradition, need assimilation to explain the general reliability of knowledge. If cognition is an act of awareness that picks out something in the world as it is present in one's perceptual field, assimilation is the becoming like that which we pick out in the world. A theory of assimilation guarantees the content of our perceptual acts because perceptual contents are produced by the knower and the known coming to be united as like. Assimilation is then a primitive fact of the cognitive life of human beings, one that works as an explanation for the 'magical' part of cognition, the 'how we come to represent the world the way we do': we represent the world the way we do because the world presents itself the way it does, and we are constitutively sensitive to that mode of presentation, which we acquire by assimilation. Now, the definition of assimilation seems to entail a causal aspect because what we know of objects seems to depend on how these objects act upon our senses. So, the question 'what is assimilation' entails the question whether perceptual acts are brought about by the sensible thing and its properties.

The assumption of this causality can already be found in the early anonymous De anima commentary edited by Gauthier:

13 We use here the terms 'identity' and 'supervenience' in a weaker (and perhaps somewhat misleading) sense than how these terms are used in contemporary debates on philosophy of mind. We use 'identity' to express the view according to which for the subject to become aware (or cognizant) of an object simply is to become like (or be actualized by) the external object. We use 'supervenience' to express the view according to which for the subject to become aware of an object is something in addition to (and dependent on but not limited to) the subject becoming like (or being actualized by) the external object. At this level of description, we can remain neutral with respect to the nature of this becoming like and the ontological status of the incoming sensory representations. 
[P2] He [Aristotle] then inquires about the last differentia of the definition of sensation. And he says that the sensitive [power] in potency is just like the sensible, i.e., the sensible species, when the sensible intention is in the sense in actuality. And the sensitive [power] is acted upon before being sensible, but when acted upon it is assimilated to and like the sensible species. ${ }^{14}$

In his exposition of Aristotle (De anima II, c. 5: 417b19-29), this master of arts (ca. 1245-1250) elaborates on the metaphysical model underlying the epistemological account by noting that the presence of the species is responsible for perfecting the cognitive power. ${ }^{15}$ As a result, this power goes from a state of potentiality to a state of actually being like the sensed thing (ut sit tale quale sensibile). But the anonymous author further qualifies this claim by specifying that the sensible thing that the power becomes like as the result of being acted upon is the intentio sensibilis or species sensibilis. The incoming sensory information that activates the perceptual power becomes the content of that perceptual act by the assimilation of the sense power to the species. This need not entail representationalism, i.e., that the species, rather than the external thing, is the object of perceptual experience.

It would be justified to expect an explanation of how representationalism is avoided, but that is not our concern here. What is our concern, and is constitutive of this cognitive model, is that perceptual content is determined by the (causal) action of the object upon the soul, an action that causes the assimilation of the soul to the object and thus makes the cognitive act about that particular sensible quality in the world. But in order for the object's action to be significant in a cognitive sense, it must affect that which is by nature such as to be receptive of being made (or becoming) like it. Assimilation, then, is the result of both the state of readiness that defines the power as a first actuality

14 Anonymus magister artium, Lectura in librum de anima a quodam discipulo reportata II, c. 11, lectio 4 (ed. R.A. Gauthier, Rome, 1985, 288-289): "Deinde inquirit diferenciam ultimam diffinitionis sensus. Et dicit quod sensitiuum potencia est ut sit tale quale est sensibile, id est species sensibilis, cum sit iam actu intentio sensibilis in sensu. Et sensitiuum patitur ante quam sit sensibile, set quando passum est, assimilatur et est ut species sensibilis." Unless otherwise indicated, all translations are our own.

15 In this context, 'sensible species' stands for representations of sensible features of things that are issued forth from the object and received by appropriate sensory powers. There is a significant debate about the nature of the species and what it represents. For an introduction to this topic, see K.H. Tachau, Vision and Certitude in the Age of Ockham. Optics, Epistemology and the Foundation of Semantics, 1250-1345 (Leiden, 1988). See also Dominik Perler's contribution to this volume. 
and the causal efficacy of the object producing the species that activates the power's potentiality.

It could be claimed that the issue cannot be restricted to being about the causal story of how a perceptual act is brought about but must include an explanation of how a perceptual act with a specific content is brought about and how this act is an accurate representation of the external thing. This idea can be formulated in the following way:

$[\mathrm{T}]$ The object is sufficient to bring about a perceptual act in an appropriate subject that represents the object in the relevant manner.

According to this cognitive model, then, the object is sufficient to bring about a perceptual act in an appropriately endowed cognitive subject. But thesis [T] of this model includes the italicized clause 'in the relevant manner'. This is so because the object cannot be represented in all its aspects, but rather in those that are appropriate to a particular cognitive power. ${ }^{16}$ The key question is about the source of the representation, because we know that it represents only to the extent that it is caused by something that has the power to cause an accurate representation. A typical formulation of this principle is precisely the idea that the external thing is that which is needed to 'reduce', to use medieval terminology, the power to actuality. ${ }^{17}$ What makes the external thing an object of perception is its power to make a likeness of itself in the sense (sensibile facit in sensum suum simile) in a way that results in its being perceived. The anonymous master of arts (ca. 1246-1247) whose text was edited by Bázan makes this claim explicit when he interprets the Aristotelian passage "is assimilated to that" as meaning that "[the object] has generated a species similar [to itself] in the sense" (id est cum generauit similem speciem in sensu). ${ }^{18}$ This grants the veridicality of sense perception - veridicality because one can only perceive what there is because a specific perceptual power can only be activated by $a$

16 We were tempted to use 'aspect' as an umbrella-term to designate whatever kind of sensory information is transmitted and perceived, but that seems perhaps too modern for this context. The relevant manner is a proportion between what the cognitive power is sensitive to and what properties the object has that are effective in this respect. On this, see, e.g., Adam Burlaeus, Quaestiones in Aristotelis De anima, q. 9 (ed. E.A. Synan, Questions on the De anima of Aristotle by Magister Adam Burley and Dominus Walter Burley, Leiden, 1997, 53.19-20).

17 Anonymus magister artium, Sententia super II et III de anima II, c. 2, lectio 12 (ed. B.C. Bázan, Louvain-Paris, 1998, 143.233-234): "quod potentia sentiendi ad actum reducatur, aliquid extra exigitur, ut sensibile."

18 Anonymus magister artium, Sententia super II et III de anima II, c. 3, lectio 12 (ed. Bázan, 146.316-317). 
specific type of sensible property. At the same time, this makes clear the limitation of the senses in that the senses only perceive particular instances of that type of property (whereas the intellect grasps universals) and within a certain range. For Aristotle and Aristotelians, I can only perceive, e.g., a red object if there is a red object in my visual field. I can misperceive what the object having that property is or what that color is, but these are cases of judgment - thus, of the internal senses - rather than of the individual sense modality. Cases like that of the partially submerged stick perceived as bent fall into this category of perceptual errors resulting from misjudgments.

Understood in these terms, assimilation is a placeholder for a process by means of which any external thing is made present to a cognitive subject that becomes like it, meaning that the subject apprehends the external thing in the relevant manner: in a particular way and under standard conditions, as found in the external thing. ${ }^{19}$ In what follows, we consider various examples of this claim in medieval texts.

In the previous section, it was noted that assimilation can be considered in a number of non-psychological processes, for instance in connection with nourishment and growth. One of the authors we have cited as exemplifying that view is Avicenna (Ibn-Sina, 980-1037), who understands the process of assimilation as a subject's way of incorporating extraneous material into itself. But Avicenna also applies the notion of assimilation to cognition, namely when arguing thus:

$\left[\mathrm{P}_{3}\right]$ We shall say that the one sensing has the potency to become like what the sensed is in effect [i.e., actuality]: indeed, to sense is to receive the form of the object stripped of its matter in such a way that the one sensing is informed by that form; the one seeing is also like the object seen in potency, and likewise the [object] touched and the [object] tasted, etc. The first [object] sensed most certainly is that which is inscribed in the sensory instrument [i.e., sense organ] and which is apprehended. But it seems that when you say 'that is sensed which is external', the meaning of this is beyond the meaning of 'sensing in the soul'. The meaning of 'to be

19 For an overview of what those conditions are and what can happen when they are not met, see J.F. Silva and J. Toivanen, "Perceptual Errors in Late Medieval Philosophy," in The Senses and the History of Philosophy, ed. B. Glenney and J.F. Silva (New York, 2019). 
sensed externally' is that its [i.e., the object's] form is assimilated in my sense; but the meaning of 'sensing in the soul' is not that the form of the object itself is in my sense as an image, and because of this it is difficult to constitute the being of sensible qualities in bodies. But we know with certainty that, when some body affects the sense without that body being affected itself, there is a proper quality in the body that is the source of the change of the sense, without the sense changing the body. ${ }^{20}$

In this passage, Avicenna argues for a radical separation between the form as it exists in the external thing and the form as it exists in the senses. In the senses, the form is received without matter, and it is to the form existing in this way that the senses are assimilated. Perception is the result of the senses being informed by that sensible form of the object, so that without it, there is nothing to be perceived. This 'informing' guarantees that perception of sense qualities is a veridical form of awareness because the perception of a quality can only take place upon the reception of the sensible form of that quality and thus in the presence of that quality. It also means that the senses necessarily have an external cause of change, so that of two different versions of the assimilation theory in causal terms - the one in which the cognitive subject becomes like and the other in which the cognitive subject is made (to become) like Avicenna clearly advocates the latter option. In other words, for Avicenna the object is the cause of the assimilation of the cognitive subject to it. He is, however, less clear about whether one should consider this relation between the reception of the form in the sense organ and the awareness of the external thing as being one of identity or one of supervenience; that is to say, Avicenna does not provide an answer to the question whether the cognitive act about an object is determined by, but not identical to, the reception of the form in

20 Avicenna, Liber de anima II, c. 2 (ed. Van Riet, 120-122.42-56). "Dicemus autem quod sentiens habet in sua potentia fieri sicut sensatum in effectu: sentire etenim est recipere formam rei nudam a sua materia, ita ut informetur per eam sentiens; videns quoque est sicut visum in potentia, similiter palpatum et gustatum et cetera. Primum enim sensatum certissime est id quod describitur in instrumento sensus, et illud apprehendit. Videtur autem quod cum dicitur 'sentiri quod est extrinsecus', intellectus eius est praeter intellectum 'sentiendi in anima'. Intellectus enim huius quod dicitur 'sentiri extrinsecus' est quod eius forma assimilata est in meo sensu; sed intellectus 'sentiendi in anima' non est quod ipsa forma eius effigiata sit in meo sensu, et propter hoc difficile est constituere esse qualitatum sensibilium in corporibus. Sed certissime scimus, cum aliquod corpus afficit sensum, sed ipsum non afficitur, quod in ipso est propria qualitas quae est principium permutandi sensum, sensu non permutante ipsum." 
the sense organ, or instead is reducible in account to that reception. ${ }^{21}$ This is made even less clear by the somewhat misleading reference to the form as the primum sensatum, i.e., that which is primarily perceived, which runs counter to the common assumption that, for Avicenna, the object of the perceptual act is the thing itself rather than the form of the external thing impressing the sense. ${ }^{22}$

In his Long Commentary on the De anima, Averroes (Ibn-Rushd, 1126-1198) examines the issue of assimilation in very much the same terms, but introduces some important qualifications. The starting point is the notion of the potentiality and the correspondence between what is potentially $\mathrm{x}$ and what is $\mathrm{x}$ in actuality. Sense is in potentiality to $\mathrm{x}$, not as a pure disposition, but as a disposition to be completed in its actuality. This is a traditional Aristotelian formulation, according to which something is in a state of possessing knowledge but not, at the given moment, exercising it. Averroes talks about this as a "positive determination," a secundum quid potentiality, that is not a potentiality for any property but a particular potentiality for $x$ - where $\mathrm{x}$ is a kind of property, meaning that the power is able to be activated by an instance of that kind of quality. The senses are thus in a state of potentiality to - i.e., naturally constituted to be actualized by - the intentions of sensible things. The sense goes from a state of being unlike to a state of being like by a process of becoming like, which Averroes defines as a mode of being acted upon. Assimilation takes here the sense of drawing to itself that which is unlike, which is an operation of the object, or to move oneself to be that which one is unlike, which is the corresponding operation in the subject. The aspect about which Averroes diverges from Avicenna is in taking the senses to be in a state of potentiality for intentions, rather than to the things themselves. The reason Averroes offers for this view is that he thinks that if things themselves were to actualize the potentiality of the power, the power would have to become the perceived thing in a literal way, rather than simply becoming like it, in the epistemic sense of being cognitive of the external thing.

The reception in the Latin West of these commentaries by Avicenna and Averroes, together with Aristotle's own works on natural philosophy, brought to the fore questions related to cognition. Among a second wave of philosophers and theologians engaged in interpreting Aristotelian philosophy, we find

21 J. McGinnis, Avicenna (Oxford, 2010), 102, seems to settle for the latter: "That sensible form, then, impresses itself on the correlative sense organ, where the corresponding act of sensation is nothing more than that organ's being so impressed."

22 See J. Coleman, Ancient and Medieval Memories. Studies in the Reconstruction of the Past (Cambridge, 2005), 351-352. 
two important figures who have become household names for the contemporary medievalist: Albert the Great (1200-1280) and his disciple, Thomas Aquinas (1224-1274). It is worth emphasising that Albert and Thomas operate within the same conceptual Aristotelian framework and, in the case of the 'knowledge as assimilation' banner, under the influence of Avicenna and Averroes. For Albert, as for those before him,

[P4] cognition does not exist in the soul except by means of the assimilation of the knower to the known. ${ }^{23}$

In the continuation of the text, Albert provides some clues as to what he considers assimilation to be. Namely, he contrasts his view with that of the ancient thinkers, who took assimilation as entailing that the cognitive power literally takes on a certain sensible property. For these thinkers, as he reads them, the soul comes to have the form of the property just as it is found in the external thing. That is, the soul cognizes by becoming like that thing, i.e., by exhibiting a sensible property, like colour. Albert strongly denies this view, which he identifies as that of Empedocles, and argues instead that the soul is assimilated to the intentions of things and not to the things themselves. ${ }^{24}$ Nevertheless, in order to cognize something the soul needs to have in itself something of the thing cognized - something, Albert claims, that makes that which is unlike (the soul) become like the external thing. Also, at the intellectual level, the soul knows by assimilation, but here knowledge is of the principles of things, their essences, rather than some representation of a particular thing in the world. Even then, Albert remarks, assimilation is best conceived of as a process by means of which one comes to be aware of external things. ${ }^{25}$ This requires the external thing to make itself known, which it does by means of species or intentions. ${ }^{26}$ Albert makes the same point once more in the following passage:

$\left[\mathrm{P}_{5}\right]$ Nobody has knowledge of anything if its species or essence is not in the knower; so, if angels know things, either the species or the essence of these things is in those knowers. The first is evident from the fact that

\footnotetext{
23 Albertus Magnus, De anima I, tract. 2, c. 2 (ed. Borgnet, 139b): "Cognitio non existit animae nisi per assimilationem cognoscentis et cogniti."

24 Albertus Magnus, De anima I, tract. 2, c. 2 (ed. Borgnet, 140a): "Assimilatio fit per intentiones rerum, et non per essentias earum, eo quod intentio lapidis est in anima, et non ipse lapis."

25 Albertus Magnus, Super IV libros Sententiarum I, d. 28, a. 10 (Opera omnia Xxvi, ed. A. Borgnet, Paris, 1893, 71b).

26 Albertus Magnus, Super IV libros Sententiarum I, d. 36, a. 2 (ed. Borgnet, 206b).
} 
assimilation between knower and known is necessary [for knowledge], and, as Augustine claims, there is only assimilation in one of two ways: (i) when the thing is essentially in the knower, as, for instance, charity, the intellect itself, and God and so on, or (ii) the species of the thing [known] is in the intellect [of the knower]. ${ }^{27}$

Hence, by assimilation, what is external to the soul is processed and gains a mental expression, as a 'likeness' or 'similitude'. In that sense, and insofar as the truth is measured in terms of correspondence or conformity between what is in the mind and the world, assimilation is the criterion of truth: the degree of assimilation determines the degree of truthfulness of this correspondence or conformity. ${ }^{28}$ Significant for this is Albert's claim that the object, as a substance, is the real efficient cause insofar as it has the power to produce species of itself. Therefore, what is cognized is the object rather than the representing species.

Thomas Aquinas does agree to a large extent with his teacher on this matter, as the following passage makes clear:

[P6] assimilation is not required for cognition except insofar as the knower must in some way be united to the thing known. However, the union by which the thing itself is united by its own essence with the intellect is more perfect than if it were united by its likeness. ${ }^{29}$

Aquinas here presents an important argument that shifts the discussion from being about assimilation, as the process to become like the object, to being about the object's mode of presence. ${ }^{30}$ In a sense, this may be seen as a reference to Averroes and his discussion of assimilation as the cognitive power being affected by the intention of a sensible thing. But this still does not answer

27 Albertus Magnus, Super IV libros Sententiarum II, d. 3, a. 14 (Opera omnia XxviI, ed. A. Borgnet, Paris, 1894, 88b): "Nihil cognoscit aliquis cujus species non est in ipso cognoscente, vel essentia: si ergo Angeli cognoscunt res: ergo species rerum, vel essentia est in ipsis cognoscentibus. Prima patet per hoc quod oportet esse assimilationem inter cognoscentem et cognoscibile: et non est assimilatio (ut dicit Augustinus) nisi altero duorum modorum, scilicet, quod res sit essentialiter in cognoscente, ut charitas, et ut ipse intellectus, et Deus, vel hujusmodi: vel quod species rei sit apud intellectum."

28 On this issue in Aquinas, see Jörn Müller's contribution to this volume.

29 Thomas Aquinas, De veritate, q. 8, a. 1, ad 7: “... ad cognitionem non requiritur assimilatio nisi propter hoc ut cognoscens aliquo modo cognito uniatur. Perfectior autem est unio qua unitur ipsa res per essentiam suam intellectui, quam si uniretur per similitudinem suam."

3o On this, see Jörn Müller's contribution to this volume. 
the question of what the nature of assimilation is. All we have is the general statement that the soul is potentially all things, meaning that it is capable of knowing all things. The passage from this open-ended disposition to an actual cognitive act is provided by assimilation, because any cognitive power only becomes like one (known) thing at any one time. The power goes from being in the state of being Footentiality2/actualityl, like having the capacity to see colour (a "state of preparedness for perceptual activity," as masterly put by Lorenz), ${ }^{31}$ to being Factuality2, like seeing colour. Assimilation is the perfection of the existing senses in a state of second potentiality by the action of the object via the species. $^{32}$

Aquinas makes clear that one does not cognize, in normal conditions, the species to which the cognitive power is assimilated, but rather the thing itself that the species represents. A species only becomes the object of a cognitive act in case it misrepresents the thing or is taken to misrepresent it (if the intellect has doubts that the species is doing its job) or in case one purposefully takes it as an object of inquiry in itself.

One way to clarify Aquinas' view is to think in terms of how the species comes to represent the way it does by focusing on the representation itself and on the 'being affected side' of assimilation: the kind of change that the reception of this representation causes in the perceiving subject. In other words, whether or not this change entails the taking on of the quality perceived by a physical subject (the organ) has been, and continues to be, debated in the scholarship. ${ }^{33} \mathrm{We}$, however, prefer to focus on another way of understanding Aquinas' view: by focusing on what powers the cognitive subject must possess in order to be able to become like the object known. In this case, the focus is not on the 'becoming like' per se, but rather on that which becomes

31 H. Lorenz, "The Assimilation of Sense to Sense-Object in Aristotle," Oxford Studies in Ancient Philosophy 33 (2007), 179-220, at 182.

32 According to Aristotle (De anima II, c. 5: 417a2o), things can be in a state of first potentiality, like human beings have the capacity to learn geometry; in a state of second potentiality (= first actuality), when they have learned geometry but are not currently exercising that knowledge; finally, in a state of second actuality, when they are solving a geometrical problem. The senses are in a state of first actuality (or second potentiality) prior to exercising that capacity, whereby they come to be in a state of second actuality.

33 The scholarship on this issue in both Aristotle and Aquinas is already overwhelming, so we will not attempt to contribute further to it. For references, the reader should consult, e.g., V. Caston, "The Spirit and the Letter: Aristotle on Perception," in Metaphysics, Soul and Ethics: Themes From the Work of Richard Sorabji, ed. R. Salles (Oxford, 2004), 245-320. See also Cecilia Trifogli's article in this volume, which gives an excellent rundown on the issue. 
like - the 'assimilating side'. Aquinas makes it clear that this is his view when he remarks that

$\left[\mathrm{P}_{7}\right]$ assimilation expresses a motion towards similitude, and so belongs to that which receives from another what makes it like [this other].$^{34}$

The idea is clear: assimilation has a cause that is external to the cognitive subject, but assimilation properly understood is a process of the cognitive power coming to be aware of the thing cognized. In other words, of the two alternatives presented earlier regarding the relation between object and subject, it seems clear that Aquinas is here opting for supervenience without identity. In any case, assimilation guarantees the veridicality of our perceptions, because a perception is grounded on (i) the actual existence of an object with a specific sensible quality present to us and on (ii) a cognitive power that is disposed to that sensible feature and tuned to the environment (e.g., not asleep, distracted, etc.). The presence of that object with that sensible quality results in the assimilation of the 'positively' disposed power. Assimilation in this cognitive sense may involve alteration, but it is necessarily the activity of the perceptual capacity by which the awareness of an object is realized. Understood in this way, assimilation is what makes knowledge possible and is at the same time the criterion for truth: knowing is for the knower to be assimilated to the known thing and to know is to be like the thing in the relevant manner, as truth is the conformity of thought to thing. ${ }^{35}$

We have not said much about the nature of representations qua ontological entities. Instead, our focus has been on questions such as what of the object is naturally made available to the perceptual power and what may a perceptual power be capable of representing. However, the nature of representational devices such as species became central for those authors who wished to argue against them. William of Ockham (1287-1347) is a good example of this approach. Exploring his position on the topic will allow us to understand

34 Thomas Aquinas, Summa contra gentiles I, c. 29: "Assimilatio motum ad similitudinem dicit et sic competit ei quod ab alio accipit unde simile sit."

35 Thomas Aquinas, De veritate, q. 1, a. 1, resp.: "Convenientiam vero entis ad intellectum exprimit hoc nomen verum. Omnis autem cognitio perficitur per assimilationem cognoscentis ad rem cognitam, ita quod assimilatio dicta est causa cognitionis: sicut visus per hoc quod disponitur secundum speciem coloris, cognoscit colorem." 
better the relation between causation and the constitution of mental content that is essential for the definition of cognition as assimilation. Ockham is unequivocal:

[P8] Moreover, the species is not posited except for assimilation, or to cause intellection, or for the representation of the object, or for the determination of the faculty, or for the union of the mover and the moved. The species is principally posited for these. But it should not be posited for any of these; hence, it should not be posited at all - not for assimilation, because assimilation is either in the essence and the nature of the intellectual nature by which it is assimilated to the object cognized, or it is the assimilation of the effect to the cause. It cannot be the former, because if the intellect cognizes substance, then it rather assimilates itself in its own nature to the object that is a substance than by means of a species that is an accident, because accident is less assimilated to substance than substance to substance. It cannot be the latter either, because the assimilation of the patient to the agent is such that the patient receives a certain effect caused by the agent. Rather, in this way the intellect is sufficiently assimilated [to the object] by the intellection caused by the object and received in the intellect; therefore, a species is not required. ${ }^{36}$

Ockham goes on to argue that in no instance of cognition does the intellect require assimilation to the species, because cognition can be explained as the result of the direct causal action of an external agent (object) upon the cognitive subject, without the mediation of the species. In fact, the problem with taking the species as playing an explanatory role is that one must be able to

36 Guillelmus de Ockham, Quaestiones in librum secundum Sententiarium (Reportatio), qq. 12-13 (Opera theologica V, ed. G. Gál and R. Wood, St. Bonaventure, NY, 1981, 272.17273.5): "Item, species non ponitur nisi propter assimilationem vel propter causationem intellectionis, vel propter repraesentationem obiecti, vel propter determinationem potentiae, vel propter unionem moventis et moti. Propter ista maxime ponitur species. Sed propter nullum istorum oportet ponere, igitur non est ponenda. - Non propter assimilationem, quia illa assimilatio aut est in essentia et natura intellectuali per quam assimilatur obiecto cognito, aut est assimilatio effectus ad causam. Non primo modo, quia si intellectus intelligat substantiam, tunc magis assimilatur in natura sua propria obiecto quod est substantia, quam per speciem quae est accidens, quia minus assimilatur accidens substantiae quam substantia substantiae. Nec secundo modo, quia sic est illa assimilatio passi ad agens per hoc quod recipit aliquem effectum causatum ab agente. Sed isto modo assimilatur intellectus sufficienter per intellectionem causatam ab obiecto et receptam in intellectu, igitur non requiritur species." See C. Panaccio, Ockham on Concepts (Aldershot, 2004), 29-31. 
account for its nature: either the species has the same nature as the object or a different one. If the former, can it come to exist in the cognitive power without informing or qualifying the power with the real form of the object? (Can sight take on a species of colour that is colour itself without becoming coloured?) If different, can the species nevertheless represent the thing it purports to represent? (Can the species of colour not be coloured and yet represent colour? How? $)^{37}$ Species would be useless and a concern, if they were posited, for the veridicality of perception, and as such they must be avoided. Ockham's solution is to argue against the need to posit species to explain assimilation and thus cognition.

According to Ockham's criticism, species are also not necessary for the purpose of representing an object. We cannot go here into Ockham's account of representation, but it suffices to say that he claims that for $y$ to be able to represent $\mathrm{x}, \mathrm{y}$ must first know $\mathrm{x}$. If that were the case, however, it would mean that the species theory is incorrect, because the motivation to posit the species is precisely for them to represent an object in a way that is conducive to cognition. In other words, it is by having the representation of $x$ present to y's senses that $\mathrm{y}$ is brought to cognize $\mathrm{x}$; in fact, according to some versions of the theory, the representation's being present to y's senses is for $y$ to perceive $\mathrm{x}$. Ockham, on the other hand, thinks that $\mathrm{y}$ can only cognize $\mathrm{x}$ if $\mathrm{x}$ rather than a representation of $x$ is present. This is not because Ockham simply denies the existence of representations in general, but rather because he has strong requirements for representing: he believes that only a cognitive being has the ability to represent. There are no species, because objects do not produce representations of themselves, as traditionally assumed by the species-doctrine; instead, objects present themselves to cognitive subjects, ${ }^{38}$ thereby determining their cognitive faculties and the contents of their acts. ${ }^{39}$

37 On this, see Tachau, Vision and Certitude, 134. It is important to note that Ockham's objections are significantly different from those of other anti-species theorists, for instance Peter John Olivi. One of the arguments Olivi proposes against species is that if one perceives by means of the species, one must at least also perceive the species, in addition to perceiving the object.

38 Guillelmus de Ockham, Quaestiones in librum secundum Sententiarum, qq. 12-13 (ed. Gál and Wood, 274.4-5): “... obiectum sufficienter repraesentat se in una cognitione."

39 Guillelmus de Ockham, Quaestiones in librum secundum Sententiarum, qq. 12-13 (ed. Gál and Wood, 276). This is the case with respect to intuitive cognition, that is, the cognition of something as present and existing. In the case of abstractive cognition, i.e., cognition of something without asserting its existence, a habit is sufficient (ibidem, 278). 
On Ockham's view, object and cognitive power alone are therefore sufficient to account for the production and content of a cognitive act. ${ }^{40}$ Hence, instead of saying that the object has the power to cause the cognitive act by causing the species that cause the cognitive act, according to this view the object causes on its own, i.e., without the species, the cognitive act. Otherwise, one needs to account for the nature of the species and then on the basis of this nature inquire further into how the species can be generated by the external thing it represents and how it relates to that thing. On the other hand, the cognitive power is able to be directed at the object that made itself present without the need for an internal representation of that object. It seems to us that this is not a matter of ontological parsimony, but rather a matter of the epistemic justification:41 the content of the act is the object and the intentionality of the act is its own unmediated directedness to the object. For Ockham, what explains the cognitive act as being about $\mathrm{x}$ rather than $\mathrm{y}$ is that $\mathrm{x}$ rather than $\mathrm{y}$ is the external efficient cause of the cognitive act. The act, as the effect of the action of the object, is about that which caused it rather than only that to which it is similar. ${ }^{42}$ It is the similarity relation between the object and the power and the causal relation from object-to-soul that make a given act be directed at and about a particular object in the world: only by these two requirements taken together can the conditions for veridicality as well as the accuracy conditions of cognition as being about this particular thing present to the perceiver be fulfilled. ${ }^{43}$

To conclude: in this brief overview, we have tried to show that the description of 'cognition as assimilation' does play a role in medieval philosophy. What we discovered from examining some instances of explicit use is that assimilation seems to be shorthand for two basic principles: (1) that the object causally contributes to the actualization of a cognitive power and (2) that this perceptual

40 Guillelmus de Ockham, Quaestiones in librum secundum Sententiarum, qq. 12-13 (ed. Gál and Wood, 276.2-3): "agens sufficiens est obiectum et intellectus, ut probatum est."

41 The interpretation sketched here may be contentious and merits a more robust argument than we can provide in this brief introduction.

42 On this issue, see P. King, "Rethinking Representation in the Middle Ages: A Vade-Mecum to Medieval Theories of Mental Representation," in Representation and Objects of Thought in Medieval Philosophy, ed. H. Lagerlund (London, 2007), 81-100.

43 Guillelmus de Ockham, Quaestiones in Librum Secundum Sententiarium II, qq. 12-13 (ed. Gál and Wood, 287.10-11, 16-19). “... quia per illam [speciem] non magis assimilatur intellectus uni singulari simillimo quam alteri ... Dico tunc quod intellectio est similitudo obiecti sicut species si poneretur, et non plus est similitudo unius quam alterius. Et ideo similitudo non est causa praecisa quare intelligit unum et non aliud." On this, see M.M. Adams, William Ockham (Notre Dame, IN, 1987), 80-81; and R. Pasnau, Theories of Cognition in the Later Middle Ages (Cambridge, 1997), 117. On the issue of intellectual access to the individual, see Ana María Mora-Márquez's contribution to this volume. 
object acts by means of sensible forms that, once received in the senses, bring about the assimilation of the power. Hence, the object is the causal agent and the form is the content of the assimilative perceptual act. This brings together assimilation and representation: the former is the act by means of which the cognitive power takes on the object and the latter is the content - the relevant manner - in which the object is made present to the perceiver. This model remained largely unchallenged. Whether William of Ockham was one of the exceptions or represents a trend in medieval philosophy is a subject for further research. ${ }^{44}$ For our purposes here, it suffices to note his criticism of the conclusion that cognition is a process of assimilation to sensible representations.

\section{The Contributions to This Volume}

The contributions included in this special issue all consider Aristotle's theory of perception as a process of the subject being assimilated to the object perceived, but with quite different approaches.

Cecilia Trifogli's article is a study of two medieval interpretations of Aristotle's much-discussed statement in De anima II, c. 12: 424a17-24 that the senses are receptive of the forms of sensible objects without the matter. Trifogli demonstrates that Thomas Aquinas and Giles of Rome both propose interpretations according to which the senses do not receive the sensible forms in a literal way, but in an "immaterial" (Aquinas) or "intentional" (Giles) way. The two explanations are discussed and related to the most dominant modern readings of the passage in Aristotle.

Mohan Matthen's article also focuses on Aristotle's theory of perception as assimilation of the sensory organ to the sensible form, but the approach employed is very different: Matthen identifies a number of what he takes to be weak spots in Aristotle's theories of vision and colour, such as, for instance, the position that vision is a passive reception of a quality that exists independently from the sensing subject, and the closely related problem that Aristotle nowhere seems to discuss perception of place.

Ana María Mora-Márquez maps out the development of the discussion of the problem of singular cognition in some late-medieval commentaries on

44 On this issue, see J.F. Silva, "Medieval Theories of Active Perception: An Overview," in Active Perception in the History of Philosophy, ed. J.F. Silva and M. Yrjönsuuri (Dordrecht, 2014), 117-146; and J.-L. Solère, "Durand of Saint-Pourçain's Cognition Theory: Its Fundamental Principles," in Medieval Perspectives on Aristotle's De anima, ed. R.L. Friedman and J.-M. Counet (Louvain, 2013), 185-248. 
De anima: from Siger of Brabant, who claims that the intellect cannot know the singular, because the metaphysical incompatibility between the two makes assimilation of the subject to the object impossible, via John of Jandun and John Duns Scotus to John Buridan, who argues that the metaphysical differences between the intellect and the individual do not prevent the subject from knowing the object and that genuine singular cognition is indeed possible.

Dominik Perler's article treats the medieval theological discussion of how the soul after death, being separated from the senses and, consequently, lacking the ability to abstract intelligible species and assimilate sensible forms, can still cognize the material world. Perler shows how Matthew of Aquasparta proposes the solution that without the body the soul can assimilate the sensible forms directly and without being affected by the material thing. The article also highlights the methodological importance of the discussion for the further development of the philosophical tradition.

Finally, Jörn Müller argues that Aquinas' exposition of his definition of truth as an adaequatio or a conformatio rei et intellectus shows that Aquinas understands truth as an assimilation between the intellect and the object, and that this fact speaks against the common opinion that Aquinas can be regarded as an early representative of the so-called correspondence theory of truth. Müller's article also demonstrates that some problematic aspects of Aquinas' theory of statements about non-being are ultimately due to his notion of truth as assimilation and of falsehood as failed assimilation. 